\title{
The impact of incentives on Employees turnover at Pakistan InternationalContainer Terminal Limited ("PICT") with respect to the different age brackets
}

\author{
Mohammad Atiq ${ }^{1}$, Afshan Bhatti ${ }^{2}$ \\ ${ }^{I}$ MS/MPHIL Degree Program Batch \# 03, Hamdard University, Karachi Pakistan \\ ${ }^{2}$ Assistant Director, QCC, PSQCA
}

\begin{abstract}
The aim of this study is to examine the impact of selected incentives on employee's turnover at Pakistan International Container Terminal Limited with respect to the different age brackets.

The results of study shall make the management to visualize the actual scenario, however the conclusions on the basis of analysis might inspire Management of the company, to think and take measures to mitigate the problem and retain their precious employees by aligning the incentives with the needs of the employees as well as to compete with the market competitive pay-scales. The data shall be collected by using stratified random sampling technique. Structural questionnaires comprising the validity of incentives regarding the age brackets of employees will be adopted, through direct interviewing the individuals. After data collection, results shall be generated and analysis would be carried out to support or reject the research analysis. The significance and its limitations are also discussed.
\end{abstract}

\section{Introduction:}

A great amount of worldwide wealth occurs in a form of human capital therefore managing human resources plays a crucial role in a process of increasing companies' effectiveness. One of the most important functions of Human Resource Management is to design the compensation \& benefits (C\&B) of the employees. These C\&B should be reviewed and revised on the basis of need of the Employees as well as the market competitiveness of the pay-scales. Although, some of research suggested that money is not as potent as it seemed to be, many companies tried to implement monetary incentives as their main tool to motivate employees. (Frey \&Osterloch, 2002) But still the crucial factor behind continuing the relationship with the Organization, is the appropriate monetary or non-monetary benefits.

The increasing trend in the employee's turnover at PICT for the last two years has startled the management to investigate and find the root cause behind the increasing trend.

\section{Objectives of the study:}

The intention of this research based thesis is to:

- analyse and interpret the increasing trend Employee turnover at PICT with respect to employees in different age groups suggest the Management to act strategically recommend adjustments to the incentives of respective employees

\section{Scope of study:}

The study is an attempt to study the preferences about incentives from Senior Executives level, Officer level, supervisory level, workmen level employees with respect to different age brackets.

It is aimed to analyze the current incentive's format and examine their relation with different age levels and influence on the separation of employees from the organization.

It is assumed that all the other parameters other than the ones defined in the questionnaire do not have any impact on the employee' turnover.

\section{Problem Statement:}

The research is aimed to study "The impact of incentives on Employees turnover at Pakistan International Container Terminal Limited ("PICT") with respect to the different age brackets".

\section{Research Question:}

The aim of the study is to understand that; does the increasing trend of employee turnover have any relation with employee's incentive in different age groups. This study will search for the answer to the question if monetary incentives are as important as they are said to be and if they can be exchanged by other, more cost efficient and equally effective. 
Managers who know the answer will be able to use the most efficient strategy to motivate their employees and possibly to avoid unnecessary costs.

Finally, the research conducted for the aim of this project might inspire Management of the company, to think and take measures to mitigate the problem and retain their human capital.

\section{Assumptions:}

Some generic attributes are taken for the study; however there may be many more which can impact the employee's turnover linked with the appropriate incentive plan. The research will be focused only on these parameters and will give a glance of the existing situation in order to understand their effects. The sample selected for the experiment may not reflect the choices and priorities of all the employees, because the social status of every individual also plays an important role in defining and understanding his priorities with relation to the job. So it is assumed that the other unconsidered parameters do not have any impact on the researchable attributes.

\section{Research Methodology \& Design:}

Research methodology is the process of systematically solving the research problem. It may be understood as a science of study how research is done scientifically. A research design is the arrangement of condition for collection and analysis of data in manner that aims to combine relevance to the research purpose with economy in procedure.

Research design is needed because it facilities the smooth sailing of research operation, thereby making research as efficient as possible, yielding, and most information with minimal expenditure of effort, time and money.

We will be using the inductive approach to study for the actual reasoning behind our problem statement, from the gathering the facts and creating a theory on the basis of the facts. The keywords used to search were: "employee turnover", "incentives", "rewards", and "work attitudes".

\section{Data Collection:}

The research had adopted two types of data namely:

i) Primary data

Primary data was collected from responds through a well-structured questionnaire through interviews of the respondents.

ii) Secondary data

Secondary data was used in the introduction part of the company profile and collected from the company records and company website.

\section{Limitations:}

Due to the scope of this research there are several limitations that need to be addressed. Only five parameters have been selected to gather the information for the analyses purpose, assuming that remaining parameters do not have any influence on the research study. Keeping in view that the other parameters cannot be kept as constant because they do have impact on the employee turnover but the study is to look only from one end and subsequently for aggressive working other parameters can be added into it to obtain more in depth information.

\section{Sample:}

A sample of sixty individuals was selected randomly from a total population of 300 employees. The sample was subdivided into four categories on the basis of age groups. As per the following table:

\begin{tabular}{|c|c|}
\hline Age Brackets & Sample Size \\
\hline$<24$ & 15 \\
\hline $25-35$ & 15 \\
\hline $35-45$ & 15 \\
\hline $45-60$ & 15 \\
\hline Total No. of Samples & 60 \\
\hline
\end{tabular}

Table 1

\section{Questionnaire:}


A closed ended questionnaire was designed to obtain the information with four ratings criteria, from Strongly Agree to Disagree. Instead of having the questionnaire filled by the responder, every individual was approached and the responses were received through interview process. However to remove the biasness element the data was gathered through individuals not belonging to Human Resource Department.

\section{Choosing factors of investigation:}

For the investigation purpose and gathering the data following parameters were taken:

i. High Salary

ii. Non-Monetary Benefits

iii. Retirement Benefits

iv. Educational Assistance

v. Other Internal Facilities

\section{Data Analysis and Interpretation of the Results:}

All the information gathered through the questionnaire was reflected in a tabular form and are presented as table 2 .

\section{Interpretation of the Results:}

On the basis of the data in table 2, the feedback from individuals from each category received on the basis of 6 parameters of preferences was bifurcated following results were drawn to their interpretation was also concluded in the shape of below results:

\begin{tabular}{|c|c|c|c|c|c|}
\hline $\begin{array}{l}\text { Age } \\
\text { Groups }\end{array}$ & Preferences & $\begin{array}{l}\text { Strongly } \\
\text { Agree }\end{array}$ & Agree & $\begin{array}{l}\text { Partly } \\
\text { Agree }\end{array}$ & $\begin{array}{c}\text { Dis } \\
\text { agree }\end{array}$ \\
\hline \multirow[t]{6}{*}{$<24$} & High Salary & 15 & 0 & 0 & 0 \\
\hline & $\begin{array}{l}\text { Non-Monetary } \\
\text { Benefits }\end{array}$ & 8 & 7 & 0 & 0 \\
\hline & $\begin{array}{l}\text { Retirement } \\
\text { Benefits }\end{array}$ & 0 & 15 & 0 & 0 \\
\hline & $\begin{array}{l}\text { Educational } \\
\text { Assistance }\end{array}$ & 13 & 2 & 0 & 0 \\
\hline & Job Surety & 2 & 13 & 0 & 0 \\
\hline & $\begin{array}{ll}\text { Other } & \text { Internal } \\
\text { Facilities } & \\
\end{array}$ & 10 & 5 & 0 & 0 \\
\hline \multirow[t]{6}{*}{$25-35$} & High Salary & 12 & 3 & 0 & 0 \\
\hline & $\begin{array}{l}\text { Non-Monetary } \\
\text { Benefits }\end{array}$ & 8 & 7 & 0 & 0 \\
\hline & $\begin{array}{l}\text { Retirement } \\
\text { Benefits }\end{array}$ & 8 & 7 & 0 & 0 \\
\hline & $\begin{array}{l}\text { Educational } \\
\text { Assistance }\end{array}$ & 14 & 1 & 0 & 0 \\
\hline & Job Surety & 10 & 5 & 0 & 0 \\
\hline & $\begin{array}{ll}\text { Other } & \text { Internal } \\
\text { Facilities } & \\
\end{array}$ & 11 & 4 & 0 & 0 \\
\hline \multirow[t]{6}{*}{$36-45$} & High Salary & 11 & 4 & 0 & 0 \\
\hline & $\begin{array}{l}\text { Non-Monetary } \\
\text { Benefits }\end{array}$ & 11 & 4 & 0 & 0 \\
\hline & $\begin{array}{l}\text { Retirement } \\
\text { Benefits }\end{array}$ & 10 & 5 & 0 & 0 \\
\hline & $\begin{array}{l}\text { Educational } \\
\text { Assistance }\end{array}$ & 5 & 10 & 0 & 0 \\
\hline & Job Surety & 13 & 2 & 0 & 0 \\
\hline & $\begin{array}{ll}\text { Other } & \text { Internal } \\
\text { Facilities } & \end{array}$ & 13 & 2 & 0 & 0 \\
\hline \multirow[t]{6}{*}{$46-60$} & High Salary & 8 & 7 & 0 & 0 \\
\hline & $\begin{array}{l}\text { Non-Monetary } \\
\text { Benefits }\end{array}$ & 13 & 2 & 0 & 0 \\
\hline & $\begin{array}{l}\text { Retirement } \\
\text { Benefits }\end{array}$ & 15 & 0 & 0 & 0 \\
\hline & $\begin{array}{l}\text { Educational } \\
\text { Assistance }\end{array}$ & 2 & 13 & 0 & 0 \\
\hline & Job Surety & 14 & 1 & 0 & 0 \\
\hline & $\begin{array}{ll}\text { Other } & \text { Internal } \\
\text { Facilities } & \\
\end{array}$ & 12 & 3 & 0 & 0 \\
\hline
\end{tabular}

Table 2 


\section{Result 1:}

High Salary
\begin{tabular}{|c|c|c|}
\hline Age Groups & Strongly Agree & Agree \\
\hline$<24$ & 15 & 0 \\
\hline $25-35$ & 12 & 3 \\
\hline $36-45$ & 11 & 4 \\
\hline $46-60$ & 8 & 7 \\
\hline
\end{tabular}

Table 3

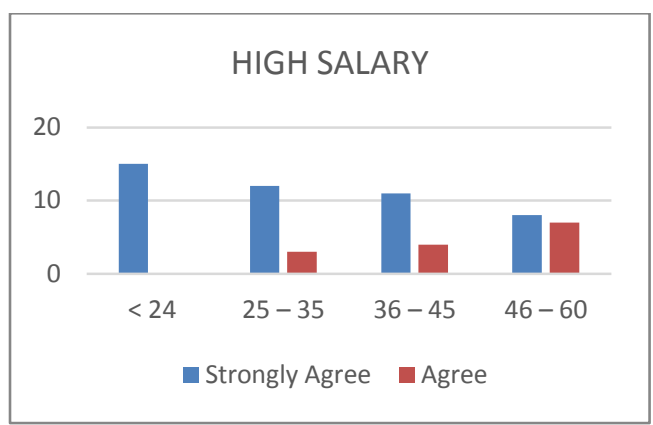

Figure 1

\section{Interpretation of Results 1:}

It can be seen that the individuals in age brackets from 24 to 45 years are more inclined towards high salary. As an employee crosses this ceiling he is more inclined towards other benefits which are more than just salary. $77 \%$ people responded with strong agreement.

Result 2:

Non-Monetary Benefits

\begin{tabular}{|c|c|c|}
\hline Age Groups & Strongly Agree & Agree \\
\hline$<24$ & 8 & 7 \\
\hline $25-35$ & 8 & 7 \\
\hline $36-45$ & 11 & 4 \\
\hline $46-60$ & 13 & 2 \\
\hline
\end{tabular}

Table 4

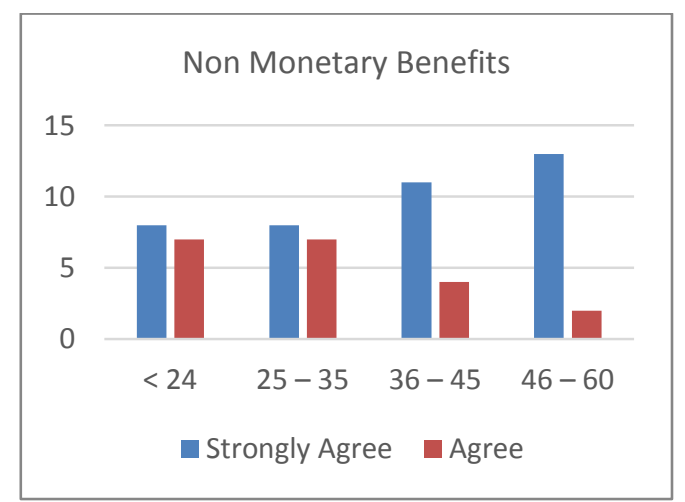

Figure 2

\section{Interpretation:}


It can be seen that the individuals in age brackets from 36 to 60 years are more inclined towards NonMonetary benefits alongwith the salary. As an employee crosses this ceiling from 35 years he is more inclined towards benefits which are more non-monetary. $67 \%$ people responded with strong agreement.

\section{Result 3:}

Retirement Benefits
\begin{tabular}{|c|c|c|}
\hline Age Groups & Strongly Agree & Agree \\
\hline$<24$ & 0 & 15 \\
\hline $25-35$ & 8 & 7 \\
\hline $36-45$ & 10 & 5 \\
\hline $46-60$ & 15 & 0 \\
\hline
\end{tabular}

Table 5

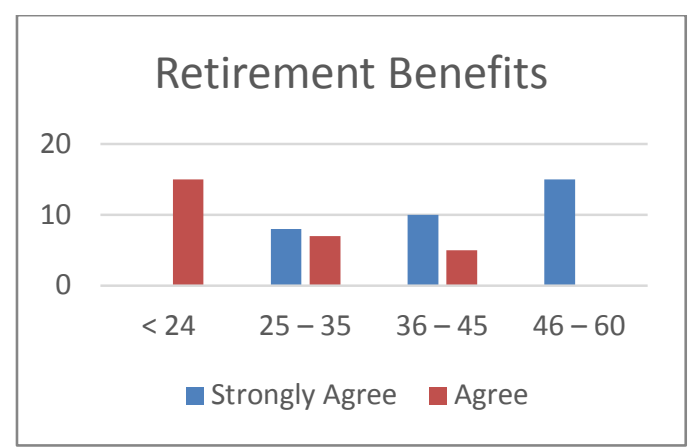

Figure 3

\section{Interpretation:}

Individuals below 24 years are least interested in the retirement benefits. It can be seen that the individuals in age brackets from 36 to 60 years are more inclined towards the retirement benefits. As an individual reaches this slab from 36 years, they need more stable job and try to stay and work at the same level of job, with his experience in his relevant field. 55\% people responded with strong agreement.

\section{Result 4:}

Educational Assistance

Educational Assistance
\begin{tabular}{|c|c|c|}
\hline Age Groups & Strongly Agree & Agree \\
\hline$<24$ & 13 & 2 \\
\hline $25-35$ & 14 & 1 \\
\hline $36-45$ & 5 & 10 \\
\hline $46-60$ & 2 & 13 \\
\hline
\end{tabular}

Table 6

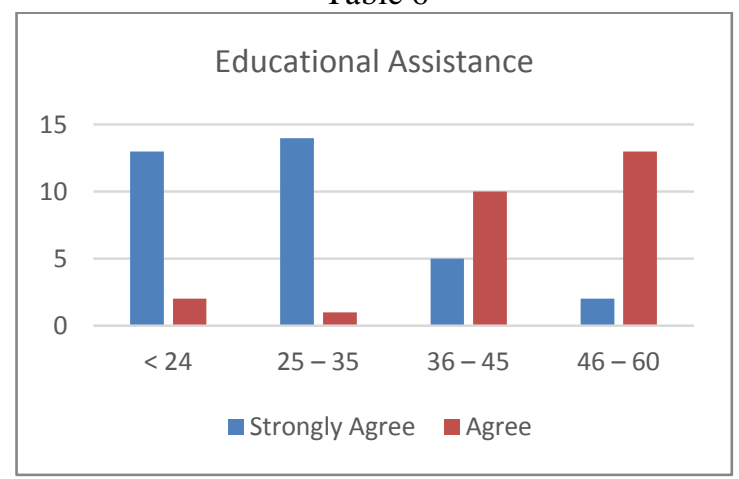

Figure 4

Interpretation: 
It can be seen that the individuals in age brackets from 24 to 35 years are more inclined towards educational assistance. As an employee crosses this ceiling of 35 years he is less inclined towards benefits which are more than just salary. $57 \%$ people responded with strong agreement

\section{Result 5:}

\begin{tabular}{|c|c|c|}
\hline Age Groups & Strongly Agree & Agree \\
\hline$<24$ & 2 & 13 \\
\hline $25-35$ & 10 & 5 \\
\hline $36-45$ & 13 & 2 \\
\hline $46-60$ & 14 & 1 \\
\hline
\end{tabular}

Table 7

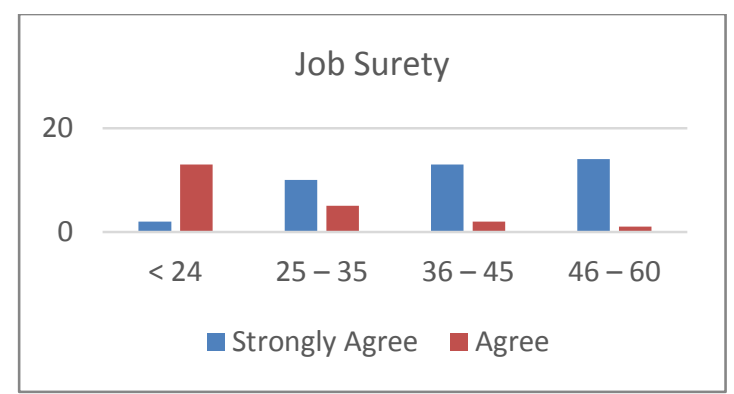

Figure 5

\section{Interpretation:}

It can be seen that the individuals in age brackets from 36 to 50 years are more inclined towards Job Surety. An employee below this limit is less inclined towards job surety. $65 \%$ people responded with strong agreement

Result 6:

Other Internal Facilities

\begin{tabular}{|c|c|c|}
\hline Age Groups & Strongly Agree & Agree \\
\hline$<24$ & 10 & 5 \\
\hline $25-35$ & 11 & 4 \\
\hline $36-45$ & 13 & 2 \\
\hline $46-60$ & 12 & 3 \\
\hline
\end{tabular}

Table 8

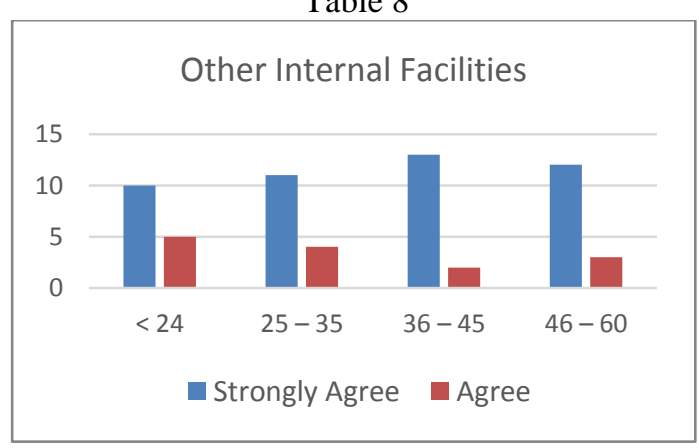

Figure 6

\section{Interpretation:}

It can be seen that the individuals in age brackets from 36 to 45 years are more inclined towards the internal facilities. As an employee crosses this ceiling of 35 years he is more inclined towards other benefits rather than the monetary benefits. $77 \%$ people responded with strong agreement.

\section{Result 7:}




\section{Interpretation of all the parameters:}

To interpret a result on comprehensive basis, reflection of all the parameters in relation to their preferences rate has been taken as follows:

\begin{tabular}{|c|c|c|}
\hline & $\begin{array}{c}\text { Strongly } \\
\text { Agree }\end{array}$ & Agree \\
\hline High Salary & 46 & 14 \\
\hline Non-Monetary Benefits & 40 & 20 \\
\hline Retirement Benefits & 33 & 27 \\
\hline Education Assistance & 34 & 26 \\
\hline Job Surety & 39 & 21 \\
\hline Other Internal Facility & 46 & 14 \\
\hline
\end{tabular}

Table 9

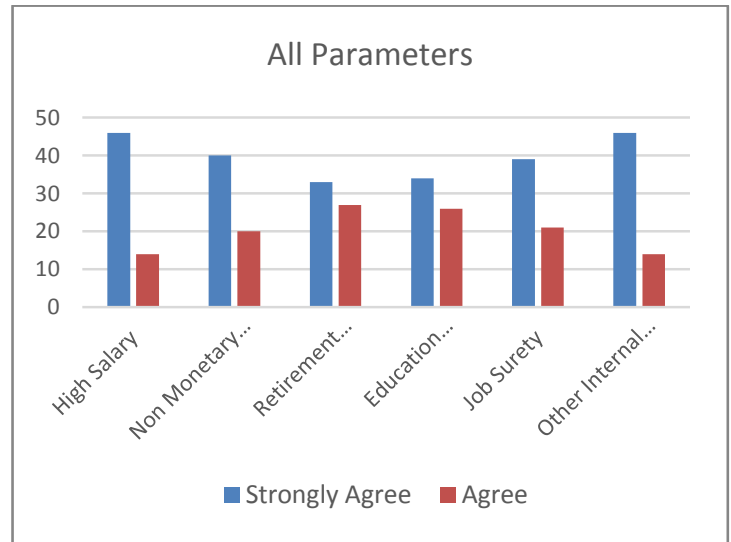

Figure 7

\section{Interpretation:}

\begin{tabular}{|c|c|c|}
\hline & Strongly Agree & Agree \\
\hline Mean & 39.67 & 20.33 \\
\hline Percentage & 66 & 34 \\
\hline
\end{tabular}

Representing the proportion of responses and presenting through graphs it revealed that maximum portion of agreement exists in the High Salary and the Other Internal Facility.

$66 \%$ of the responders strongly agree that all these attributes are important however the high salary, other internal facility and the Non-Monetray benefits are the core and play an important role in keeping and continuing their relationship with the Organization.

However 34\% have different perception and have greater interests in the retirement benefits and the Educaiton facility provided by the company.

\section{Discussion:}

According to the results analyzed and interpreted in previous section, one can easily understand the priorities of the employees with respect to their age brackets they belong to. It is quite evident from all the feedback that the incentives of any sort are important for every individual however the priorities may change in different age groups. The reason behind these motives is the career life cycle which forces a human to adopt and vary its demands in accordance with his need of planning his future. This life cycle can be broken into four phases.

At the starting first phase of the career a person is young and has lower level of liabilities, so wants to learn but with maximum monetary benefits which can provide ample support for his living. He wants to learn more and more to make himself capable of advancing ahead in his further career.

Reaching to his second phase of career he needs and wants to be at a higher level in monetary as well as non-monetary benefits, since at this age his social status changes and he wants to become a responsible and self-dependent individual. 
In the third phase of career he needs to have a stable job with regular source of earning and nonmonetary benefits as well, because at this age when his family expands so he needs more stable social and professional life. At this stage he is little concerned about the future and takes some interest in the retirement benefits as well.

In fourth phase, this is the phase when an individual had reached optimum of his career and the maturity stage goes towards a declining trend. He is knowledgeable enough to manage things with experience; however the professional learning does not require many efforts. He plans for retirement when he needs more and more monetary retirement benefits to support his grown up children. So their priorities are more inclined towards the retirement benefits.

In these different stages of professional priorities are changing with time to time, due to which for an organization it becomes difficult how to fulfill the needs of its employees. Complete satisfaction with the job and the benefits becomes difficult which results in a perturbed employee planning, to move towards the prospects which are better for his present and future and can fulfill his needs.

It important for the management of an organization to understand the psychology of its employees, only then a strategic decision can be taken to mitigate the risk which can result in the shortfall of capable and efficient manpower for running their business.

It is imperative to note that no employee is totally convinced that the incentives are not important, but every individual was found to be with a perception that any benefit which can help him to make his need fulfilled, is crucially important for him and unless and until the benefits are in line with his needs, he would never break the relationship with the organization.

\section{Conclusion:}

It is quite evident from the analysis and interpretation that incentives have great relationship with the employee's turnover of different age groups. Whatever the age bracket it may be, it is important to cater the employees with the right incentive, only then an employee can be retained. It is also observed that a variation in the type of incentive is also important and purely depends upon the age brackets. The reason behind this unrest and increasing trend of employee's turnover at PICT, is due to unmatched incentives as compared to the job and the market. A proper focus on the areas of improvement in the enhancement shall be beneficial for the organization in retaining the right persons on board.

It has been concluded that the Management of PICT should take a serious note on the employee's retention otherwise soon it will be losing the most skilled professionals which shall ultimately impact the overall business operations.

\section{Recommendations:}

As per the outcomes of the investigation and its interpretation, it is recommended that all types of incentive are important for all the employees, they just need it to match with priorities in according with social and professional status.

- Conduct employee's satisfaction survey to obtain an idea about the actual need of the employees.

- Obtaina salary survey to check and compare its own level of compensation with the market pay scales.

- Focus on the age groups of 24 to 30 years; realign their incentives and workout for their development, providing right knowledge of right skill shall make the employee to stay longer than the expected.

- Realign the retirement benefits of middle age group employees, because they are highly skilled and experienced and losing them might impact the overall operations.

- Adjust the internal facilities to satisfy the needs of middle and off middle age groups, by further surveying and gathering the information on their actual needs.

- Motivate the employees by granting non-monetary benefits to the employees considering it as their priority.

\section{References:}

[1] Official website of PICT www.pict.com.pk

[2] Discussion / talk with various categories of employees.

[3] Book of Human Resource Management by Gary Dessler (12th Edition)

[4] Website http://en.wikipedia.org/wiki/Human_resource management

[5] Research on Motivation by Michal Kirstein Aarhus School of Business Aarhus University

[6] Frey, B., \&Osterloch, M. (2002). Successful Management by Motivation -Balancing Intrinsic and Extrinsic Incentives. Zurich: Springer 